\title{
SMALL STATES AND THE EU: DOES THE EU PROMOTE SECESSION WITHIN EU MEMBER STATES?
}

\section{Estados pequeños y Unión Europea: ¿̇promueve la Unión Europea la secesión dentro de sus Estados miembro?}

\author{
NÚRIA GONZÁLEZ CAMPAÑÁ \\ Universidad de Barcelona \\ nuria.gonzalez@ub.edu
}

Cómo citar/Citation

González Campañá, N. (2020).

Small states and the EU: Does the EU promote secession

within EU Member States?

Revista de Estudios Políticos, 190, 43-70.

doi: https://doi.org/10.18042/cepc/rep.190.02

\begin{abstract}
This article reviews to what extent the EU integration process has had an impact, although unintended, in the consolidation of pro-independence movements across Europe. The article will show that, due to global trade and the legal norms against aggression put in place after WWII, it is now easier being an independent small state than it was before 1945. It will be shown that this is particularly true in the European context. Moreover, European regions play a very limited role in the EU governance and the EU remains predominantly a matter for states and the EU's own institutions, which provides an additional incentive for those seeking statehood. The examples of the Scottish and Catalan pro-independence movements are taken into account to show that the European dimension played a pivotal role in their consolidation. However, the article also nuances this statement and points out the ambivalent position of the EU: although the EU might be providing a unique economic (legal, as well) framework for the feasibility of new small states in Europe, it has also shown resilient support in favour of EU Member States legal orders. In this sense, it emerges as an additional layer of difficulties for any non-consensual and unlawful independence process.
\end{abstract}




\section{Keywords}

European regions; pro-independence movements; small States; economic interdependence; EU membership.

\section{Resumen}

Este artículo analiza en qué medida el proceso de integración europea ha podido tener un impacto, aunque involuntario, en la consolidación de movimientos independentistas en regiones europeas. El trabajo constata que después de la Segunda Guerra Mundial el escenario internacional es particularmente propicio para el surgimiento de Estados pequeños independientes y que las condiciones que lo posibilitan son especialmente idóneas en el contexto europeo. Se toman en consideración los movimientos independentistas en Escocia y Cataluña para comprobar que en ambos casos la dimensión europea juega un papel relevante en su consolidación. Sin embargo, el artículo también revela una paradoja: aunque la UE pueda ofrecer un marco económico y jurídico que rebaja las incertezas de cualquier proceso de independencia, al mismo tiempo se ha erigido como garante del orden constitucional de los Estados miembros y, en este sentido, emerge como una capa adicional de dificultades si el proceso de independencia que se lleva a cabo no es consensuado y no se adecúa al ordenamiento jurídico del Estado en cuestión.

\section{Palabras clave}

Regiones europeas; proceso de independencia; Estados pequeños; interdependencia económica; pertenencia a la UE. 


\section{CONTENTS}

I. INTRODUCTION: SMALL STATES WITHIN THE EU. II. TODAY BEING A SMALL STATE IS EASIER THAN IT USED TO BE: 1. Approaching the concept of small State.

2. Global trade and economic openness: 3. Legal norms against aggression. III. SMALL STATES WITHIN THE EU. DO THEY HAVE SPECIFIC ADVANTAGES? IV. REGIONS WITHIN THE EU. DOES THE ROLE AND INFLUENCE OF THE REGIONS IN THE EU SATISFY THOSE MOVEMENTS WITH STATEHOOD ASPIRATIONS? V. CASE STUDIES: HISTORICAL IMPORTANCE OF THE EU FOR SCOTTISH AND CATALAN PRO-INDEPENDENCE MOVEMENTS: INDEPENDENCE IN EUROPE. VI. CONCLUDING REMARKS. BIBLIOGRAPHY.

\section{INTRODUCTION: SMALL STATES WITHIN THE EU}

Today, being ${ }^{1}$ a small state is easier than before and being a small state within the EU is even easier. It will be shown that the EU is not merely a passive witness of European pro-independence movements, but to a certain extent (unintendedly) it provides a unique framework for the feasibility of new states in Europe. The EU alters the traditional calculus of opportunities of secessionist movements. While public international law does not offer either incentives or disincentives to secession, the EU, instead, offers very clear prospects of what membership offers. In other words, one could argue that the EU has created a "safety net that makes it easier for [those with statehood aspirations] to contemplate independence" (Connolly, 2013: 54). The EU umbrella would permit carrying out a risky project (independence, by definition, implies uncertainties) with a lifeboat (i.e. EU). But EU position is also ambivalent. It has proven to be an additional difficulty for those pro-independence movements eagerly seeking independence. The EU lack of support in the 2014 Scottish referendum and the 2017 EU fierce opposition to the Catalan pro-independence revolt have shown that the EU can also emerge as a guarantor of Member States' constitutional legal orders. It can also "complicate the process of secession" (ibid.: 54).

1 Note that I am not saying "becoming", since I am not implying here that the process to become an independent sovereign State is a simple one. 
This article proceeds in four parts: the first one explains why today being a small state is easier than it used to be. This is basically due to two reasons (Fazal and Griffiths, 2014): a) growth of economic interdependence and b) changes in the security environment for states. Then, the position of small states within the EU will be described, highlighting the fact that the European integration strengthens the abovementioned factors and becomes an almost ideal security organization for its Member States (Wivel, 2005: 394). The third part outlines the role played by the regions in the EU making clear that for those with national aspirations the regional policy of the EU is far from satisfactory, which turns into an additional incentive for seeking statehood. The fourth part will discuss the importance of EU membership for both Scottish and Catalan independence movements, that through their slogans and manifestos have stated a continuous desire of remaining inside the EU (although EU responses to the 2017 Catalan crisis outbreak might have altered popular support to EU membership among those in favour of secession from Spain). In this part, however, the article will also show the ambivalent position of the EU, since it has proven to be an additional layer of difficulties if the secession attempt is carried out against the will of the EU Member State concerned.

It should be noted that this article is not concerned with the moral legitimacy or the political convenience of pro-independence movements in well-functioning democracies. It assumes as a fact that in a few European regions there are strong pro-independence movements challenging the territorial status quo and intends to highlight how certain systemic changes and, particularly, the EU have played a role in the consolidation of these pro-independence movements. But, at the same time, the EU has proved to be a powerful tool in the hands of the EU Member States to prevent non-consensual and unlawful secession.

\section{TODAY BEING A SMALL STATE IS EASIER THAN IT USED TO BE}

\section{APPROACHING THE CONCEPT OF SMALL STATE}

Interdependence has made the distinction between large and small states less relevant. In fact, almost all European countries are becoming small since their influence in world affairs is decreasing (Antola, 2002: 72). Besides, the category of small states itself covers countries with many differences (in terms of population, GDP and historical background) (ibid.: 72). Notwithstanding the above, there are still significant differences between countries like, on the one hand, Germany, France or the UK and, on the other hand, Luxembourg, 
Malta or Cyprus, traditionally considered small states. And, at the same time, there are some common traits among the latter. This is not the place to rehearse at length the discussion about the concept of small states. It is a highly-contested concept among international relations scholars, but at the end of the 60s Robert O. Keohane offered a definition that has become classic: we understand small states as those "that can do little to influence the system-wide forces that affect them, except in groups which are so large that each state has minimal influence and which may themselves be dominated by larger powers" (Keohane, 1969: 296). Katzenstein (2003:11) has pointed out that when talking about small states what really matters, the first and most important variable, is the perception of vulnerability.

Today the minimum consensus seems to revolve around two ideas: a) small states must adapt to their environment, rather than affect or, needless to say, dominate it and b) small states seek influence through membership of multilateral organizations (Wivel, 2005: 395). This is a particularly interesting characteristic for the purpose of this article. In effect, scholars tend to agree that small states promote international organizations since although "they may be able to do little together, they realize they can do virtually nothing by themselves" (Rothstein, 1968).

Another common characteristic of small states is that they tend to promote external trade and favour free trade arrangements (Keating and Harvey, 2014: 55), which leads us to one of the reasons that explain why today being a small state is easier than it used to be (Campbell and Hall, 2015: 6). First, because of global trade and economic openness and second due to the legal norms against aggression in place after World War II. Thus, "systemic changes have made independent statehood a more desirable commodity" (Fazal and Griffiths, 2014: 81). In the second part, it will be shown that the $\mathrm{EU}$ integration process reinforces these two factors.

\section{GLOBAL TRADE AND ECONOMIC OPENNESS}

Does size matter when it comes to the viability of a state? Now it seems that the size of the state is not as important as it used to be in order to be viable in the international stage. Historically, there were important advantages of large size among states. "The larger state can allow the realization of more gains from trade by providing a larger free trade area, and per capita defence costs should tend to fall because of simple geometry - doubling the area of a state usually less than doubles the border needing defence and so more resources are available per linear mile" (Bean, 1973: 214).

The debate about the optimal size of the state from an economic point of view was vigorous at the end of the $20^{\text {th }}$ century. In 1991 Robert J. Barro 
published an op-ed article in which he defied the view of economic unviability for small states. According to him, " $t \mathrm{t}]$ here is no relation between the growth or level of per-capita income and the size of a country, whether measured by population or area. Small countries, even with populations of as little as a million, can perform well economically, as long as they remain open to international trade. In fact, smallness tends to encourage openness because the alternative really would be a nonviable economy".

Later, the work of Alberto Alesina (colleague of Barro at Harvard University) and Enrico Spolaore became seminal for the literature on the "optimal size of nations". Alesina and Spolaore argue that free trade and the fall of transport costs have almost turned irrelevant (to some extent) the size of the state. Thus, one of the reasons to explain why there are almost 200 states in the world is the international economic integration (Alesina and Spolaore, 1997: 1028).

Needless to say, the main historical reasons to explain that the number of UN country members has risen from nearly 50 to about 200 are the end of colonialism and the collapse of the Soviet Union. However, this economic literature pretends to highlight the fact that in a world of an open economy like the current one there is no clear relationship between size and GDP growth. In effect, these authors consider that in an open economy the size of the country is not as important as in a closed economy because the territory does not determine the size of the market anymore. "Thus, the "economically viable" size of countries depends on the trade regime. While small countries may not be viable in a world of trade barriers, they may be prosperous in a world of free trade and global markets" (Alesina and Spolaore, 2003: 82).

In general, a country's market will be given by its domestic market and part of the world market, depending on the country's degree of international openness. If there are economies of scale to the size of the market, larger countries can be expected to do better economically than smaller countries (all other things being equal) when international openness is low, but political size should become less relevant as economic integration increases. Thus, the "viable" size of a country decreases with international openness (id.).

That is why " $t]$ he benefits of large countries are less important if small countries can freely trade with each other". (Alesina and Spolaore, 1997: 1041) In effect, "small countries can prosper with free trade, while size matters in a world of trade restrictions" (Alesina and Spolaore, 2003:172).

In other words, states can afford to be small as long as they are open. Small states are especially aware of the need to be open to international trade and embrace globalization to a higher extent than larger countries. Donald 
Wittman shares this opinion about feasibility of small states in an open economy and considers that "[a]n international regime of free trade among nations allows for smaller scale political units because economic production is not limited by the demand and supply of domestic markets" (Wittman, 2000: 870). In conclusion, the number of small states can "easily" increase when free trade across countries increases.

With these references, it is not implied that international economic openness is the only (or the main) reason to explain the change in the territorial size of countries. There are other variables to be taken into account to predict the size of nations, as for instance the political regime type or the level of homogeneity, and it is not clear either whether such variables are wholly satisfying (Lake, 2004: 708, 719). But even if economic openness is not the only or main cause of small statehood (this discussion goes beyond our concern), what has been proved true is that it is a common trait among viable and successful small states (Katzenstein, 1969: 16). To sum up, economic openness enables the viability of small states. These arguments highlight an important and straightforward fact to assess secession in the $21^{\text {st }}$ century: from an economic standpoint and thanks to international openness being a small viable independent state is significantly easier today than it was centuries ago.

In their concluding remarks, Alesina and Spalaore (2003: 213-214) go further and argue that thanks to free trade,

Catalonia is a region that may not "need" Spain if it were to become a member of the European Union. To put it differently, once a region is a member of a large common market, including even a common currency area, and can enjoy free trade, the incentives for the region to seek independence or autonomy increases. The national government is much less important for the economy of the region. [...] the cost of being politically small is decreasing with economic integration. In Europe, we see that many regions can afford to be independent if they enjoy the benefits of the European common market.

This is what Michael Keating (2004: 369) seems to be highlighting when he argues that "independence within Europe may represent an attenuated and less risky form of independence, since many of the externalities are catered for".

In fact, in a 2014 Credit Suisse report, both the potential independent states of Catalonia and Scotland would rank higher than Spain and the UK in the Human Development Index. Since the report does not specify the political status of those independent countries and it does not refer to the EU membership issue, one has to assume that their calculations have been made 
considering that those states, once (and if ever) independent, would remain within the EU.

To conclude, let us clarify one point. The abovementioned arguments are not implying nor suggesting the inevitable success of small entities. Success, of course, requires many factors (e.g. political stability, the strength of the institutional framework and the Rule of Law, research and development capabilities, etc...). What is merely being highlight here with the focus on trade openness and world's markets integration capacities is simply that the current scenario (despite some signals pointing at globalization in reverse) is more favorable to small states (if they know how to manage it) than it used to be in the past.

\section{LEGAL NORMS AGAINST AGGRESSION}

Another important characteristic of today's world that permits the secure existence of small states is the legal framework against conquest. Today aggression across recognized borders has become unacceptable. But this was not the case until the second half of the $20^{\text {th }}$ century. Until then the Thucydides teachings from the Melian dialogue ("the strong do what they can and the weak suffer what they must") proved to be accurate. It was the legitimacy of conquest's era. At the end of World War II the Allied Powers decided to strongly support the norm of integrity of interstate boundaries (Atzili, 2012: 19). In effect, after the World War II in the international order there is a stable bargain among the major powers: "the bargain rests on the expectation that if any one major power seeks to change interstate borders by force, others may follow, to the detriment of the first" (Fearon, 2004: 394). The implicit deal being the following: "If you do not seek to change interstate borders by force, then neither will we" (ibid.: 397) That deal, formalized in the UN Charter (Zacher, 2001: 222), was a tool to avoid major powers or coalitions of major powers going around carving up lesser powers on an ad hoc basis. That would make all states, including the major powers themselves, less secure.

In effect, since 1945 "the major powers have refrained from interventions to carve up a previously recognized state to make new states without the consent of the state. In marked contrast to prior great power politics, the major powers since the 1950s have stuck to the norm of "no border changes imposed by force" with very few exceptions" (Fearon, 2004: 412). While approximately $80 \%$ of territorial wars led to re-distributions of territory for all periods prior to 1945 , this figure dropped to $30 \%$ after then, which means that "the decline of successful wars of territorial aggrandizement during the last half century is palpable" (Zacher, 2001: 244). The absence of wars implying boundaries change was particularly remarkable in the Western hemisphere. With this behaviour, the international community has honoured the 
formal equality of sovereign states proclaimed in the UN Charter. Today small states fear less military invasions. According to the Center for International Development and Conflict Management of the University of Maryland, this new safety net environment has made secession more attractive around the globe (Gallagher, 2011: 278).

Let us just compare the security feelings (especially within the EU) with the concerns of European national communities at the beginning of the $20^{\text {th }}$ century. According to Bartkus (1999: 34):

At the turn of the century, even though they suffered repression, weaker distinct communities in Europe did not normally contemplate independence as a remedy for their grievances. An investigation of Czech demands for reform and devolution within the framework of the Austro-Hungarian Empire reveals an acute awareness on the part of Czech leaders that they would surely face the prospect of even worse subjugation if they were to secede. Furthermore, a short examination of the events leading to the creation of Yugoslavia indicates the extent to which concerns for security preoccupied the Serb, Croat, and Slovene communities. Yugoslavia's hasty creation was to a great extent due to each community's similar judgment that its own particular interests would be better defended by integration into a larger and more powerful state of their creation.

In today's world (at least in the Western hemisphere) no one fears the territorial invasion of a neighbouring country.

These two reasons (i.e. growth of free trade and the increasing respect for the proscription that force should not be used to alter interstate boundaries) might help to explain why small statehood is today more viable than it used to be (Walter, 2006: 105). In effect, the growing economic liberalization and the emergence of a safety net in the post-World War II period has promoted a global governance that guarantees the survival of states in general and small states specifically. Or as Fazal and Griffiths (2014: 101) put it: "the benefits of statehood have been increasing, while the costs, at least for rulers, have not seen similar increase". This is particularly true in the European context, which provides a particularly safe haven as long as EU membership is assured. In fact, European integration early objectives were the maintenance of peace in Europe and an open international political economy. This is precisely what a pro-independence movement in a European region looks for: an organization that reinforces the physical protection of the new entity and promotes an integrated economy. Fazal and Griffiths (2014: 93) sustain that

of all the regional and global economic international organizations existing today, the European Union appears to provide the biggest gain for its members. 
And indeed, newborn European states are quick to apply for EU membership, although gaining membership is a long road. The European Union is viewed as an extremely important organization to join by European proto-states such as Catalonia, Scotland and Flanders.

Here Fazal and Griffiths point out two distinct cases. On the one hand, the cases of those states emerging after the collapse of the Soviet Union, eager to join the EU and to adapt the Copenhagen criteria (i.e. the EU as an incentive to foster Rule of Law, democracy and respect for human rights, among other requirements) and on the other hand the cases of regions within Member States seeking independence.

\section{SMALL STATES WITHIN THE EU. DO THEY HAVE SPECIFIC ADVANTAGES?}

Before the creation of the European Coal and Steel Community in 1951 war was the norm in the European soil (Linde Paniagua, 2013: 22). After some centuries where the physical survival of European states was under threat due to the European great powers wars, "the European integration project emerged as an almost ideal security organization for the region's small states [...] providing a bulwark against the instability and conflict characteristic of European great power relations prior to the cold war" (Wivel, 2005: 396). Within the EU framework, the peaceful resolution of conflicts approach replaced the superpowers "as the primary source of order" (ibid.: 397) As has been affirmed, the legal norm against aggression has been mainly honoured throughout the world. The record of accomplishment, though, lies in the Western Hemisphere. The EU has been a successful story of peace for all its members (thanks, of course, to the NATO and the US collaboration). Thus, if today's world is a safer world for small states' survival, the EU arena (with its large single market and the free movement provisions) adds an additional layer of certainties.

Bearing in mind that no organization can turn upside down the world's power relations, small states understand that "within the EU they can exert more influence and achieve more than they would outside it" (Antola, 2002: 74). Small states in Europe have seen that "their relative standing on the international scene has been strengthened (as a result of EU membership and its amplifying effects for a member's voice) while norms they have championed (emphasis on the civilian and cultural projection of identity, on international law and institutions, and so on) have to a large extent become distinguishing features of the Union's own international identity" 
(Lavdas, 2010). According to Wivel, "[s]mall state influence is protected by formal EU institutions making traditional power capabilities less important and by codifying what is deemed acceptable behaviour within the EU" (Wivel, 2010: 23). The strengthening of their voice (Lavdas, 2010) is due also to "the formal equality of small and big Member States, including the lack of a European equivalent to the UN Security Council" (Wivel, 2005: 399), which ensures a unique voice opportunity for everyone in the decision-making process. Particularly because in the EU most of the decisions are reached through consensus. In effect, "[s]mall state influence is protected by the consensus culture of EU decision-making” (Wivel, 2010: 23).

One of the many historical examples of small states influences within the EU, highlighted by the former leader of the Scottish Nationalist Party (SNP) Alex Salmond, was the 1992 Danish referendum. After the referendum on the Maastricht Treaty was rejected, the then still European Community provided Denmark with some exceptions that eventually led to a ratifying popular vote. That fact "enabled the SNP to point to the crucial role played by a small nation within the EC. Alex Salmond pointed to the fact that the Danish referendum result 'finally crushed the claim that small nations can have no influence in the European Community"' (Lynch, 1996: 48). Another similar and more recent example are the legal guarantees offered to Ireland to secure a "Yes" vote in the 2008 second Lisbon Treaty referendum (Pech, 2009). Besides, according to Thorhallsson, small states are focused on a narrow set of economic interests, being only rigid on matters of economic priority and offering flexibility and willingness to compromise on all others. This makes them very successful agents in negotiations: "The administrations of the smaller states concentrate solely on the sectors where they have important interests as they are trying to maximize their benefits for them. They are active in pressing for their interests in these sectors, whereas decisions in other sectors are left for the other states to decide" (Thorhallsson, 2000: 69). Lavdas (2010) agrees: "small states in Europe have generally been able to pursue successful and influential strategies of international adjustment, based on a clearer focus on a narrow set of economic interests and objectives".

This approach enables them to work with the Commission to get their favoured issues acted on in the Council. In effect, small states have built a special relationship with the Commission as they see it as a neutral institution that at least takes into consideration the views of all member states. Thus, small states have opted for cooperation (probably because only large states can pay the price of confrontation), becoming very active only when necessary to avoid damaging consequences (Thorhallsson, 2000: 151-155). Furthermore, being small provides another advantage when it comes to negotiate and later implement the decisions adopted at the EU level. 
"Smallness provides the advantage of effective national policy co-ordination" (Antola, 2002: 73). In the 90s, for instance, "small member states [were] at the forefront in transposing internal market legislation" (ibid.: 81). This is not only a sign of effectiveness, but also of political enthusiasm and eagerness to cooperate with EU institutions. Also, the presumed overrepresentation in the Council voting system and in the European Parliament has been a recurrent argument when considering the advantages of small states within the EU (Katzenstein, 2003: 25). It is true that the existing system is seen by larger member states as containing an over-representation of smaller states. However, institutional changes since the Nice Treaty (2001) have diminished the weight of small member states (Antola, 2002: 77). In any event, the practical relevance of that assumed advantage has also been put into question, since the logics of the decision-making both in the Council and the European Parliament go beyond the concrete number of votes (before November 2014) or seats (Moberg, 2002: 277-278), given the consensus-culture within the EU framework. And, again, as has been already stated, this culture of consensus gives some advantages to small states: "under consensus decision-making, losers are compensated to some degree and cannot necessarily simply be outvoted and ignored" (Heisenberg, 2005: 81).

An historical example of the beneficial effects of EU integration process in small states is to be found in the break-up of Czechoslovakia. Despite the peaceful and amicable agreement to divide the country, bilateral trade between the two new entities declined significantly. Thus, in 1991, around $50 \%$ of Slovakia's trade was with the Czech Republic and this figure dropped to about 25\% in 1991. Czech trade with Slovakia declined from around $30 \%$ in 1991 to about $10 \%$ in 1997 . However, "integration with the EU mitigated the impact of the break-up to some extent, as much of the decline in Czech-Slovak trade reflected the growth in trade with other countries, in particular with the EU" (Credit Suisse, 2014). With these remarks, we are not neglecting nor are we avoiding the challenges of small states. The aim of these lines was simply to highlight the sheltering umbrella the EU represents for new small states, particularly those emerging out of a former dictatorship. Here the remarks of professor Weiler (2012) when affirmed that the EU cannot end up providing an incentive for political disintegration, since there is a fundamental difference in the welcoming into the Union of a Greece, a Portugal or a Spain out of dictatorships and Catalonia, Scotland or Flanders, already part of a functioning democracy. For him, providing these regions with incentives to EU membership would mean "betraying the very ideals of solidarity and human integration for which Europe stands". 


\section{REGIONS WITHIN THE EU. DOES THE ROLE AND INFLUENCE OF THE REGIONS IN THE EU SATISFY THOSE MOVEMENTS WITH STATEHOOD ASPIRATIONS?}

Let us now turn to examine the representation and voice the EU offers to Europeans regions. As it is well known, the European integration process has shifted Member States competences upwards. Thus, in the case of decentralized Member States, some current EU competences set rules for implementation in the fields of competences formerly exercised by regions in the domestic arena. Since the EU remains predominantly a matter for States and the EU's own institutions (Weatherill, 2005: 29), the consequence is the erosion of the regional scope of autonomy and political decision. This widely known problem has existed since the beginning of the EU integration process, but it became particularly acute in the 1970s and 1980s. First, because of the political decentralization trends in many European countries. At the start of the European integration process only Germany had a federal structure. This changed with the decentralization of Belgium and Italy in the 1970s. Second, with the entry of new decentralized Member States in the 1980s like Spain and then in the 1990s with the decentralization process (devolution) in the United Kingdom.

Compensation mechanisms to this erosion are limited and they vary considerably between Member States (Jeffery, 2005: 34). In fact, it could be argued that by now the regional participation in the EU decision making depends more on the Member States' willingness than on EU law provisions (Castellà, 2008: 83). However, what matters here is to underline the limited presence of the regional dimension in policy-making at the European level. In the 1980s German Länder were pioneer in demanding greater regional control of European policy. Their complaints (also promoted by the European Commission who favored a greater regional participation) were partially satisfied with the Maastricht Treaty, which meant the biggest step so far in the regions' fight for participation within the EU. During those years, it became popular to envision a "Europe of the Regions". Some even thought that "a role for regions within the EU might be a useful mechanism for accommodating nationalities" (Keating, 2004: 375), a way to counter-act pro-independence movements turning their demands into obsolete pretensions.

Despite the initial optimism, Maastricht reforms (i.e. the creation of the Committee of the Regions, the introduction of the principle of subsidiarity and the legal possibility for regional ministers to join or even lead national delegations at the Council of Ministers) gave only a limited recognition to regions (Jeffery, 2005: 35). And subsequent Treaty reforms like the Lisbon Treaty (2007) only added modest impetus to a regionalized Europe. The study 
of the Committee of the Regions (CoR) is a good example of a failed attempt to provide regional recognition. The CoR is an advisory political body that provides the regional and local levels with a voice in EU policy development and EU legislation. From the perspective of those regions with national aspirations the CoR has some important flaws:

- Irrelevance within the EU institutional architecture because of its limited advisory role: the European Commission, the Council of the EU and the European Parliament must consult the CoR when drawing up legislation on matters concerning local and regional government. However, since CoR opinions are not binding, very frequently the EP and the Council just ignore them. (Jeffery, 2005:36) This is why the CoR has been described as a "talking shop".

- The diverse and asymmetric membership (ranging from regions with legislative powers, regions that are administrative units, provinces and city councils) blurs the status of those who consider their regions as stateless nations. Representatives of regions with legislative powers have refused to engage actively in the CoR, since they do not want to be treated like local entities or administrative units (Pons et al, 2012: 179).

- There are better routes for regions to make their voice heard. For instance, many regions have established offices in Brussels in an effort to improve their access to the EU decision-making. This shouldn't be a surprise either. One of the dramas for sub-national entities is that it is even difficult to merely track what is being discussed at EU level. (Weatherill, 2005: 131). Besides, very often Members of the European Parliament are an appropriate channel to lobby on behalf of the concerned region. (Castellà, 2008: 67) And last but not least, lobbying the central government to advance a concrete regional policy is also a regular and effective mechanism.

The Lisbon Treaty did strengthen the role of the CoR by providing standing before the European Court of Justice whenever it considers the principle of subsidiarity has been violated. However, the CoR still remains far from the European Parliament's second chamber once envisioned. As for the principle of subsidiarity and the regional dimension, it seems that since the Lisbon Treaty there was a sort of redefinition. Before, it was mainly read as limiting the scope and influence of the EU and preserving EU Member States' position (Davies, 2006: 66). Now it looks that this idea of vesting the authority over any given policy at the lowest possible political level should necessarily include regions, not just Member States. This approach is justified, 
among others, by Article 4.2 TEU, which included for the first time the respect to regional and local self-government structures as a duty of the EU, and by Article 10.3 TEU, which establishes that "decisions shall be taken as openly and as closely as possible to the citizen". Furthermore, the early warning system mechanism ${ }^{2}$, introduced by Protocol No 2 on the Application of the Principles of Subsidiarity and Proportionality, requires national Parliaments to consult regional Parliaments with legislative powers when assessing EU legislative draft. However, practice has showed the limited effects of this mechanism.

Regarding the possibility of opening the state delegations at the Council to regional Ministers (which was introduced by the Maastricht Treaty and was not been modified by the Lisbon Treaty), it should be noted that this is an option that depends entirely on the political will of the Member State. In the case of Spain, for instance, it is possible to incorporate in the state delegation (in five of the nine formations of the Council) a regional Minister as the AC's representative (Castellà and Kölling, 2015: 271). That representative works under the supervision of the head of the Spanish delegation (Morata, 2010: 141). In the case of Belgium, on the contrary, regional Ministers are able to represent by his own the Belgian state in many Council formations. Although this possibility does not apply to those meetings concerning matters that are exclusively federal: general affairs, ECOFIN, budgetary negotiations, justice, telecommunications policy, development aid and civil protection (Swenden, 2010: 24).

Regions have also created informal networks to advance their interests: for instance, the Conference of European regions with Legislative Power (REGLEG), an informal network dedicated to achieve a greater role in the EU for legislative regions. Its demands included enhancing their role in the Council, an appropriate involvement of regional parliaments and the right to bring actions before the European Court of Justice where the prerogatives of the regions are threatened. Interesting to note that they do not have activities since 2013. This type of international activity carried out by sub-state actors has been described as "paradiplomacy".

\footnotetext{
Article 6 of the referred Protocol sets forth that "Any national parliament or any chamber of a national parliament may, within eight weeks from the date of transmission of a draft legislative act, in the official languages of the Union, send to the Presidents of the European Parliament, the Council and the Commission a reasoned opinion stating why it considers that the draft in question does not comply with the principle of subsidiarity. It will be for each national parliament or each chamber of a national parliament to consult, where appropriate, regional parliaments with legislative powers".
} 
Despite some evidence that regions have had "some" impact on debates within the EU (Burrows, 2010: 124), the SNP continues to argue that "only with statehood could "regions" exercise effective voice at the European level" (Laible, 2008: 207). According to nationalist voices within European regions, the EU has made very limited steps to accommodate the participatory demands of certain sub national entities. "European strategies tend to underestimate the importance of regional governments in delivering on key strategic goals" (Burrows, 2010: 122). The EU, they argue "bolsters the significance of statehood by limiting full participation in its institutions to member states" (Connolly, 2013: 54), and by doing that it has given supporters of independence an additional reason (or excuse) to claim that only statehood guarantees full political participation in Europe. This emphasis on nationstates has been seen by some analysts as a way of placing a premium on becoming a state (Keating, 2004: 383). Scully and Wyn Jones (2010: 243-245) conclude that because some European regions have not come to play the sort of role they envisaged, there has been a "gradual cooling attitude toward the European regional policy".

Not surprisingly, failed regionalization of the EU might have had an impact on demands for independence. Within a true Europe of the regions the independence of subnational regions might have looked like a meaningless prospectus. A traditional demand of Catalan nationalism shares this analysis by arguing that it is false to think that the Europe of regions that we effectively have is an equivalent to the European recognition of stateless nations. For them, today, stateless nations are almost invisible for European institutions. (Mira, 2007: 72-73)

\section{CASE STUDIES: HISTORICAL IMPORTANCE OF THE EU FOR SCOTTISH AND CATALAN PRO-INDEPENDENCE MOVEMENTS: INDEPENDENCE IN EUROPE}

So far, it has been underlined that the EU integration process (with all its safety nets that reduce the uncertainties of a small sovereign State and its inability to recognize an important role for regions) provides those who seek for independence with arguments and incentives. This section will test the accuracy of such argument and will show that it has to be nuanced. To what extent the European dimension and the EU membership debate have played a role in the Catalan and Scottish pro-independence movements? For instance, has the European dimension (e.g. EU membership after independence debate) any impact in the popular support towards independence? Although Scotland is abandoning the EU together with the rest of the UK, the Scottish example 
is still a relevant historical case to assess the impact of the EU within the pro-independence process of a European region.

Let's start with the Catalan case. The classic work of Donald L. Horowitz about the logic of secessions in economically regional advanced groups gives a first good explanation of the phenomenon. Needless to say, the following explanations are not sufficient to understand a complex process like a pro-independence movement. However, they do have a strong connection with the European integration phenomenon and that is why they deserve to be pointed out. Horowitz observes that advanced regional groups in advanced nations "are likely to have a regional economic grievance. Advanced regions usually generate more income and contribute more revenue to the treasury of the undivided state than they receive. They believe that they are subsidizing poorer regions" (Horowitz, 2000: 249-250). In fact, one of the example Horowitz employs is Catalonia. It should not surprise that, at least at the beginning of the Catalan pro-independence process in 2012, one of the complaints of the movement was the Catalan taxpayers "unreasonable" contribution to the Spanish poorest regions (Bel, 2013: 165). In fact, one of the battle cries of the Catalan nationalist movement used to be "Madrid ens roba" (Madrid is robbing us), a slogan imported from Italy, popularized in the 1990s by the Lega Nord ("Roma Ladrona"). In effect, exacerbated by a context of recession, some narratives stress that Catalonia has disproportionally contributed to central state budgets and receives low public investment in return. (Della Porta et al., 2020: 163).

Yet, Horowitz also sees that secessions have countervailing considerations: "Such groups are likely to export surplus capital and population outside their region. Their prosperity generates investment that does not respect regional boundaries" (Horowitz, 2000: 250). In other words, advanced regions also take advantage of domestic markets. This might have been a traditional scenario in Catalonia, when in the past Catalan industry was sheltered by a high Spanish protective tariff (Laitin, 1989: 300). Things have changed greatly, of course, and in the EU context protectionism is not a possible policy anymore. In the last decades, Catalan industry has evolved and there is an increasing internationalization of Catalan products with the most relevant partners located within the EU. However, still today the Spanish market represents around 35\% of Catalan exports (Comerford et al., 2014: 89). As Horowitz explains, the prosperity of advanced regions depends on a web of interregional economic relations. According to him "the lure of interests and opportunities throughout the undivided state is enough to ward off the possibility [of secession]" (Horowitz, 2000: 253).

Under ordinary circumstances, secession could imperil the strong economic ties (among which export statistics is only a single indicator) 
between Catalonia and the rest of Spain. But as Connolly (2013: 94) clearly points out:

The EU, however, changes the calculus for advanced regions such as Catalonia (or Flanders, or the Basque Country or Veneto): following independence, if EU membership were secured, Catalans would still enjoy access both to Spanish markets and the markets of other EU member states. Thus, the EU may be viewed as eliminating an important brake on the separatist aspirations of economically advanced regions.

This statement, however, needs to be specified. First, EU membership after independence cannot be taken for granted, on the contrary, given the unanimity rule (Article 49 TEU). Second, one thing is the legal access to Spanish markets and the other thing (difficult to anticipate) is the frontier effect that could harm the economic perspectives of Catalan products and services in the rest of Spain due to anger and frustration because of the secessionist move (at least in the short term) (Linde Paniagua, 2013: 38). And third, the EU single market cannot still be compared with a national market. Barriers to trade remain between EU Member States, particularly in the services sector. In any event, there is a general consensus (and it is also the perception among the Catalan population) that EU membership, if kept, would alleviate at least some of the economic burdens secession could entail.

In the Scottish case, where Scottish GDP per capita is similar to that of the UK as a whole, some would argue that economic arguments in line with Horowitz's position cannot help to explain Scotland's nationalist surge. However, pro-independence support has grown, among other reasons, "by the discovery, in the late 1960s, of big oilfields under the North Sea. It gave the nationalist more to be angry about — and an argument for why Scotland would be better off alone" (The Economist, 2014). The early 1970s rallying cry "It's Scotland's oil!" provided the SNP with a key electoral impetus. It partially explained, for instance, the exceptionally good electoral results of the SNP in the February and October 1974 general elections, in which popular support increased to around 30\% from around 12\% in 1970.

Needless to say, Scotland maintains strong economic links with the rest of the UK, even stronger than in the Catalan case. In the Scottish case, the economic ties with the rest of the UK are outstanding. For example, around $64 \%$ of Scottish exports go to the rest of the country, while Scots exports to the EU do not represent more than 19\% of the Scottish trade (Export Statistics Scotland, 2018). These ties, unlike in Catalonia, seems not to be put fundamentally at risk in the event of an independent Scotland, since it does not seem that such scenario would trigger large resentment among the rest of 
the country. At least this was the situation back in the 2014 referendum, for the British and the Scottish governments had already reached an agreement on holding a legal referendum. However, today this is unclear, since the new Prime Minister, Boris Johnson, has refused to allow for a second referendum, which could lead to a major confrontation (Brooks, 2020).

Both the former Scottish Prime Minister Alex Salmond and the current one, Nicole Sturgeon, have always underlined that an independent Scotland would necessarily remain within the EU and that the Scottish independence would be based on interdependence not only with the rest of the UK, but also with Europe. So, the idea to link independence and EU membership has been a constant trend in the most recent Scottish pro-independence movement. For instance, before and during the 2014 referendum campaign, the Scottish government insisted the "smooth transition to full EU membership can take place on the day Scotland becomes an independent country" (Scotland Government, 2013: 13). However, EU institutions did not show that very same enthusiasm. The EU representatives did not encourage pro-independence Scots through easy accession promises. In February 2014, the then European Commission President, José Manuel Durao Barroso, said that it would be "difficult, if not impossible" for an independent Scotland to join the EU (Syal, 2014). As López Basaguren points out (2014: 82), what was particularly striking about the Scottish Government position was their lack of reference to the difficulties of Scotland remaining in Europe, for they were very well aware, first, of the need of unanimity among the rest of EU Member States and, second, of the fact that some EU Member States were willing to show strong resistance. The EU kept a highly precautionary position (if not a clear disdain), with no promises of quick and easy Scottish membership and that had an impact on Scottish population. In fact, one of the factors deciding the 2014 referendum in favor of remaining within the UK was the risk of being left out of the EU. In effect, "uncertainty remained about what was possible and about the conditions for membership. This lack of clarity enabled the pro-UK camp to make border checks and immigration key issues in the referendum campaign" (Berbéri, 2016: 28). Equally, the decisive reason that explains the new surge of the Scottish pro-independence movement is, precisely, the UK withdrawal from the EU (Sim, 2020).

The SNP, however, has not always showed this same level of Europeanism. Before the 1970s, the SNP did not pay a particular attention to Europe. In the 1975 British referendum on continued membership the SNP campaigned in favor of "No" in order to separate politically Scotland from the rest of the UK. With a "No" in Scotland and a "Yes" in the rest of the country, the "Westminster government would appear illegitimate in Scotland through endorsing continued membership of the EC when it had been rejected in 
Scotland" (Lynch, 1996: 32). However, it was not only a strategic position. There was a wide sector within the party that had taken a negative view of the EC. According to them the then EC had an undemocratic and centralist dimension (ibid.: 33) In any event, the SNP message was ambiguous. In fact, there were already voices within the party making the case for Scottish independence within the EC. In the 1970s Jim Sillars, who later joined the SNP, but was then the leader of a new party, the Scottish Labour Party, took the view that "the EC removed the negative aspects formerly associated with separatism and made independence for Scotland within the EC a more fruitful constitutional option" (ibid:: 36). At the end, in the 1975 referendum, none of the regions of Scotland voted against continued membership. The result moved the party in a more pro-European direction, emphasizing its commitment to gaining a strong role for Scotland within Europe.

In the 1980s there was a definitive shift within the party. For Lynch (ibid:: 38),

the new European policy was cautious in tone but clearly promoted Scottish membership of the EC as an aid to secession from the UK which would shield the Scottish economy from the disruption that political change could bring. [In 1983] Gordon Wilson described the new policy as a first-class way of pushing the advantages of political independence without any threat of economic dislocation. "Within the common trading umbrella the move to independence can take place smoothly and easily."

The reasons of this shift were diverse. Apart from the result of the 1975 referendum on continued membership, it should be taken into account that given the growing anti-Europeanism in the British government, there were also political benefits in playing a pro-European card, a way to show Scottish distinctiveness towards the rest of the country (ibid.: 39) Also, new leaders with innovative political ideas brought a change in the position of the SNP towards the European integration (Laible, 2008: 87). So, the new slogan (in fact, in track since 1988) was ready: "Scotland Future: Independence in Europe". As has been indicated, the adoption of such pro-European position involved "strategic considerations about making independence a safe constitutional option" (Lynch, 1996: 50). In other words, the SNP advocated instrumental support for the European Union by encouraging their supporters to view the EU as the means by which independence becomes feasible (Haesly, 2001: 97).

The victory of the pragmatic approach indicates a recognition that only in the EU would the self-governing polity survive (Laible, 2008: 206). This is consistent with recent empirical work on regional political party positions on 
Europe (with a particular study of the SNP) which suggests that "regional political parties are likely to be strongly supportive of European integration because market integration makes small states or autonomous regions more viable economic entities" (Kincaid Jolly, 2007: 112).

Catalan nationalism, unlike the Scottish nationalist movement, has traditionally shown a particular attachment to the idea of Europe, historically inclined to strengthen ties with Europe (Vicens Vives, 1958: 298). Assuring and strengthening the links with Europe has always been a powerful way of reaffirming Catalan identity against Spanish nationalism (Mira, 2007: 70). The European destiny was a concern for Catalan intellectuals since the beginning of the 20th century. For instance, after the outbreak of World War I, Eugeni d'Ors, one of the most relevant Catalan intellectuals of the time, published a Manifesto in Journal de Genève entitled "Pour l'Europe. Un manifest des écrivvains et de penseurs de Catalogne" (De Pedro and Solé, 1999: 45). Some Catalan federalist believed that Europe would be the solution for historic regions and in the interwar period many of them took part in the Minority Congresses promoted by the League of Nations (De Pedro and Solé, 1999: 46). Then, in the aftermath of the World War II the European integration process was seen as the opposite to the Franco regime. It kept its appealing effect among Catalan nationalists.

One of the persons who has most vigorously promoted the link between Catalanism and Europeanism is Jordi Pujol, President of the Generalitat from 1980 since 2003. In a speech delivered in Aachen in 1985 he stated that Catalonia is the only Spanish people that was born linked to Europe and not, like the others, as a reaction against the Muslims. He insisted that the objective of the other Spanish peoples was to restore the Visigoth monarchy in Toledo, while the objective of Catalans, according to him, was to promote the Carolingian empire. He said that Catalonia was the first place in Spain where Europeanism took root. Coming to Aachen meant, in his mind, not going abroad, but to the origins, since Catalonia was the first place in Spain where Europeanism took root (Pujol, 2018). In 2007, also in Germany when the region of Catalonia was the guest of honour at that year's Frankfurt Book Fair, remembering those words, Pujol added that for Catalonia, Europe always meant modernity, progress, pluralism, democracy and peaceful coexistence of languages and peoples. This supposedly close link between Catalonia and Europe is the vision that has been promoted by the Catalan nationalist movement and that has been widely delivered in Catalonia - also by the Basque nationalist narrative (Jáuregui, 2006: 253)—. In effect, in the last decades the different Catalan nationalist political parties have been almost without contestation vigorous defenders of the European integration process. "Catalonia, next independent State in Europe" used to be one of the slogans of the Catalan 
pro-independence movement. Throughout these years, polls consistently have indicated that those in favour of an independent Catalonia are significantly reduced in the event the independence process expels Catalonia from the EU and that an overwhelming $70 \%$ supports remaining within the EU in case of independence (Ubieto, 2017). It is true, however, that since October 2017 and given the clear support offered by the EU institutions in favour of the Spanish legal order, there has been a certain feeling of European disenchantment among Catalan nationalists (Pujol, 2018). Yet, Catalan nationalists have also received with joy the refusal of several European arrest warrants against former Catalan political leaders (in the context of European judicial cooperation) or the judgment of the Court of Justice of the European Union in the Junqueras case (C-502/19 ECLI:EU:C:2019:1115), whereby the Court decided the immunity of the elected Members of the European Parliament. Although the former Catalan Vice-President Oriol Junqueras has not been able to enjoy the benefits of the Court decision, it "has not been entirely pointless for other pro-independence politicians" like former Catalan President Carles Puigdemont and former Catalan Conseller Toni Comín, who were admitted as MEPs following the judgment (Sarmiento, 2020).

To sum up, in the case of Scotland the europeanism of the SNP has been labelled as utilitarian or instrumental, while the attachment to Europe lies at the heart of the Catalan nationalist movement not only because of economic convenience but also due to political and identity reasons. In both cases the only possible way to politically promote independence has been through affirming the will of maintenance of EU membership after secession. Otherwise, popular support for an independent Scotland or Catalonia declines.

However, the EU has also emerged as a key opponent of unilateral and unlawful secession attempts. Although during the first stage of the pro-independence process in Catalonia (from 2012 to 2014) the European Commission resisted all attempts to be drawn into the conflict, since 2014 (when it became clear that the Catalan government contemplated unilateralism) the new President Jean Claude Juncker responded firmly supporting the constitutional order of Spain. During those years, the Catalan government representatives were not even allowed to meet high-ranked EU civil servants at the European Commission (Molina, 2019). Despite some criticism, because of the manner in which the Spanish police enforced court rulings when trying to prevent the $1^{\text {st }}$ October referendum from happening, the European Commission did not consider that Spain was violating values contained in Article 2 TEU. Neither has the European Commission put into question the criminal procedures in Spain against the political leaders responsible for the organization of the unlawful referendum and the unilateral declaration of independence of Catalonia. Weiler (2019: 1305) explains that "the EU and its member 
states have turned a cold shoulder to the secessionist claims... [because the] very ethos of European integration discourages the Union, as such, from welcoming these movements and encouraging them by the promise of easy accession".

After the Catalan revolt, it seems clear that in the event of non-consensual and unlawful secession, EU institutions will show a fierce opposition. In this sense, the European integration process proves to be an additional difficulty if the independence process is carried out non-consensually and unlawfully. And here we find the paradox: although on the one hand the EU framework, unintendedly, has enabled European pro-independence movements to sell a politically viable project of independence within Europe (i.e. low cost independence or with reduced uncertainties) and, therefore, it has facilitated their consolidation, on the other hand the EU also becomes a strong ally of EU Member States constitutional legal orders and a strong opponent of unilateral pro-independence attempts.

\section{CONCLUDING REMARKS}

Statehood is relevant for pro-independence movements since, as Laible (2008: 23) underlines,

[Statehood] remains the sole means by which nationalists can be recognized as sovereign equals in the European political system. Regardless of the transformations of sovereignty that have occurred in EU member states over the past five decades, the state itself is still the primary means for some nationalists to achieve their goal: recognition under current EU norms as the legitimate authority over their respective territories.

In their view, statehood claims are claims for dignity, recognition and equality. In effect, nationalist parties argue that "EU integration has not erased the value of state borders and has not deprived states of so much authority that statehood has ceased to have meaning". On the contrary, statehood still matters, because states remain dominant actors in many policy functions. Besides, states are "still recognized as the primary constitutive elements of legitimate political order in the EU and in the world system more generally" (ibid.: 205).

Today's secessionist movements in West Europe have many causes and such analysis goes beyond the limits of this work. This article aims to highlight that without the perspective of the EU umbrella it is difficult to imagine some of these secessionist movements pushing so hard for independence. 
There is, at has been noted, a "growing attraction of the concept of 'independence in Europe" (Crameri, 2015: 425). But the relatively good status of small states in the EU and the lack of EU recognition towards regions might be just sophisticated arguments to justify a simpler position: they wish independence from Spain or Italy or Belgium, but they do not know what it would be like outside. However, if at least EU membership is assured (which of course is dubious due to the unanimity rule provided for in Article 49 TEU), uncertainties are reduced. As said at the beginning of the article, the EU umbrella permits carrying out a risky and uncertain process like independence with a lifeboat (i.e. the EU). If today's world is a safer world for small states' survival, the EU arena (with its large single market and the free movement provisions) adds an additional layer of certainties. However, not any type of independence process can receive the supporting umbrella of the EU. The paradox lies precisely here. Although on the one hand the EU provides a unique framework for the feasibility of small States, it also guarantees the respect of the constitutional legal orders of the EU Member States. Thus, if the independence process is carried out without the consent of the parent State and against its legal order, the EU reinforces the position of its members and adds difficulties to the independence process.

\section{Bibliography}

Alesina, A. and Spolaore, E. (1997). On the number and size of nations. The Quarterly Journal of Economics, 112 (4), 1027-1056. Available at: https://doi.org/10.1162/ 003355300555411.

- (2003). The Size of Nations. Cambridge: Massachusetts Intitute of Technology Press.

Antola, E. (2002). The Future of Small States in the EU. In M. Farrell et al. (eds.). European Integration in the $21^{\text {st }}$ century (pp. 69-85). Thousand Oaks: SAGE. Available at: https:// doi.org/10.4135/9781446221051.n5.

Atzili, B. (2012). Good Fences, Bad Neighbors. Border Fixity and International Conflict. Chicago: The University of Chicago Press. Available at: https://doi.org/10.7208/chicago/ 9780226031378.001 .0001 .

Barro, R. (1991). Small is beautiful. Wall Street Journal, 11-10-1991.

Bartkus, V. (1999). Dynamic of Secession: An Analytical Framework. Cambridge: Cambridge University Press. Available at: https://doi.org/10.1017/CBO9780511491214.

Bean, R. (1973). War and Birth of the Modern State. The Journal of Economic History, 33 (1), 203-221. Available at: https://doi.org/10.1017/S0022050700076531.

Bel, G. (2013). Anatomia d'un desengany. Barcelona: Destino.

Berbéri, C. (2016). The Impact of Scotland's Prospective Membership of the EU on the 2014 Referendum Debate: Concerns over Borders. Études écossaises, 18, 11-28. Available at: https://doi.org/10.4000/etudesecossaises.1041. 
Brooks, L. (2020). Boris Johnson refuses to grant Scotland powers to hold independence referendum. The Guardian, 14-01-2020. Available at: https://bit.ly/3hPMJGf.

Burrows, N. (2010). Scotland's European Strategy. In R. Scully and R. Wyn Jones (eds.). Europe, regions and regionalism (pp. 115-133). London: Palgrave MacMillan. Available at: https://doi.org/10.1057/9780230293151_7.

Campbell, J. and Hall, J. (2015). The World of States. London: Bloomsbury.

Castellà Andreu, J. M. (2008). Las comunidades autónomas en Bruselas: la dimensión externa en la participación autonómica en la Unión Europea. Revista d'Estudis Autonòmics $i$ Federals, 6, 37-91.

— and Kölling, M. (2015). Asymmetrical Involvement of Spanish Autonomous Parliaments in EU Affairs. In G. Abels and A. Eppler (eds.). Subnational Parliaments in the EU Multi-Level Parliamentary System: Taking Stock of the Post-Lisbon Era (pp. 269-289). Innsbruck: Studien Verlag.

Comerford, D., Myers, N. and Rodríguez Mora, J. (2014). Aspectos comerciales y fiscales relevantes para evaluar las consecuencias económicas de una hipotética independencia de Cataluña. Revista de Economía Aplicada, 64, 85-130.

Connolly, C. (2013). Independence in Europe: Secession, Sovereignty and the European Union. Duke Journal of Comparative \& International Law, 24, 51-105. Available at: https://doi.org/10.2139/ssrn.2231162.

Crameri, K. (2015). Do Catalans have the right to decide? Secession, legitimacy and democracy in the twenty-first century Europe. Global Discourse: An Interdisciplinary Journal of Current Affairs and Applied Contemporary Thought, 423-439. Available at: https://doi. org/10.1080/23269995.2015.1083326.

Credit Suisse Research Institute. (2014). The success of Small Countries.

Davies, G. (2006). Subsidiarity: the wrong idea, in the wrong place, at the wrong time. Common Market Law Review, 43 (1), 63-84.

De Pedro, P. and Solé, Q. (1999). 30 anys d'història d'europeisme català. Barcelona: Mediterrània.

Fazal, T. and Griffiths, R. (2014). Membership has its privileges: The Changing Benefits of Statehood. International Studies Review, 16 (1), 79-106. Available at: https://doi. org/10.1111/misr.12099.

Fearon, J. (2004). Separatist Wars, Partition, and World Order. Security Studies, 13 (4), 394-415. Available at: https://doi.org/10.1080/09636410490945965.

Gallagher, K. (2011). Divide and Conquer or Divide and Concede: How Do States Respond to Internally Divided Separatists? American Political Science Review, 105 (2), 275-297. Available at https://doi.org/10.1017/S0003055411000013.

Government of Scotland, Export Statistics 2018. Available at: https://bit.ly/2FQoqen.

Haesly, R. (2001). Euroskeptics, Europhiles and Instrumental Europeans. European Attachment in Scotland and Wales. European Union Politics, 2 (1), 81-102. Available at: https://doi.org/10.1177/1465116501002001004.

Heisenberg, D. (2005). The institution of "consensus" in the European Union: Formal versus informal decision-making in the Council. European Journal of Political Research, 44, 65-90. Available at: https://doi.org/10.1111/j.1475-6765.2005.00219.

Horowitz, D. (2000). Ethnic Groups in Conflict. Berkeley: University of California Press. 
Jáuregui, G. (2006). Basque nationalism: Sovereignty, Independence and European Integration. In J. McGarry and M. Keating (eds.). European Integration and the Nationalities Question (pp. 255-273). London: Routledge.

Jeffery, Ch. (2005). Regions and the European Union: Letting them in and leaving them alone. In S. Weatherill and U. Bernitz (eds.). The Role of Regions and Sub-national entities in Europe (pp. 33-46). Oxford: Hart.

Katzenstein, P. (2003). Small States and Small States Revisited. New Political Economy, 8 (1), 9-30. Available at: https://doi.org/10.1080/1356346032000078705.

Keating, M. (2004). European integration and the nationalities question. Politics and Society, 32 (3), 367-389. Available at: https://doi.org/10.1177/0032329204267295.

- and Harvey, M. (2014). The Political Economy of Small European States: And Lessons for Scotland. National Institute Economic Review, 227 (1), 54-66. Available at: https:// doi.org/10.1177/002795011422700107.

Keohane, R. (1969). Lilliputians Dilemmas: Small states in international politics. International Organization, 23 (2), 291-310. Available at: https://doi.org/10.1017/ S002081830003160X.

Kincaid Jolly, S. (2007). The Europhile Fringe? Regionalist Party Support for European Integration. European Union Politics, 8 (1), 109-130. Available at: https://doi.org/10. 1177/1465116507073290.

Laible, J. (2008). Separatism and Sovereignty in the New Europe. London: Palgrave MacMillan. Available at: https://doi.org/10.1057/9780230617001.

Laitin, D. (1989). Linguistic revival: Politics and Culture in Catalonia. Comparative Studies in Society and History, 31 (2), 297-317. Available at: https://doi.org/10.1017/ S0010417500015838.

Lake, D. (2004). The incredible shrinking State. The Journal of Conflict Resolution, 48 (5), 699-722. Available at: https://doi.org/10.1177/0022002704267766.

Lavdas, K. (2010). Normative evolution in Europe: Small States and Republican Peace. London: LEQS. Available at: https://doi.org/10.2139/ssrn.1550955.

Linde Paniagua, E. (2013). Estado versus nación. El fin de la era de los nacionalismos en Europa. Revista de Derecho de la Unión Europea, 25, 21-46.

López Basaguren, A. (2014). La independencia de Escocia en la Unión Europea. Los efectos de la secesión de territorios en la UE entre política y derecho. Teoría y Realidad Constitucional, 33, 69-98. Available at: https://doi.org/10.5944/trc.33.2014.13038.

Lynch, P. (1996). Minority Nationalism and European Integration. Cardiff: University of Wales Press.

Mira, J. F. (2007). Catalanisme: un lloc a Europa? Revista del Centre d'Estudis Jordi Pujol, 5 , 68-74. Available at: http://llull.cat/IMAGES_175/transfer04-not01-cat.pdf.

Moberg, A. (2002). The Nice Treaty and Voting Rules in the Council. Journal of Common Market Studies, 40 (2), 259-282. Available at: https://doi.org/10.1111/1468-5965.00354.

Molina, I. (2019). La crisis catalana y la influencia de España en Bruselas. Real Instituto Elcano, 25-04-2019. Available at: https://bit.ly/3mFDaxm.

Morata, F. (2010). Europeanization and the Spanish territorial state. In R. Scully and R. Wyn Jones (eds.). Europe, regions and regionalism (pp. 134-154). London: Palgrave MacMillan. Available at: https://doi.org/10.1057/9780230293151_8. 
Pech, L. (2009). The European Union's Lisbon Treaty: Some thoughts on the "Irish Legal Guarantees”. EJIL:Talk! [blog], 28-09-2009. Available at: https://bit.ly/2FZkOqg.

Pons, X., Campins, M., Castellà, J. M. and Martín, E. (2012). La acción exterior y europea de la Generalitat de Cataluña. Barcelona: CEI-Marcial Pons.

Pujol, J. (2018). Nostàlgia. AssociacióServiol. 12-11-2018. Available at: http://associacioserviol. cat/nostalgia.

Rothstein, R. (1968). Alliances and Small Powers. New York: Columbia University Press.

Sarmiento, D. (2020). MEP Immunity and the Junqueras Conundrum. EU Law Live, 15-012020. Available at: https://bit.ly/32M7pe2.

Scotland Government (2013). Scotland's future. Your Guide to an Independent Scotland. Available at: https://www2.gov.scot/Resource/0043/00439021.pdf.

Scully, R. and Wyn Jones, R. (2010). Conclusions: Europe's persisting regions. In R. Scully and R. Wyn Jones (eds.). Europe, regions and regionalism (pp. 239-245). London: Palgrave MacMillan. Available at: https://doi.org/10.1057/9780230293151_14.

Sim, P. (2020). Scottish independence: Could a new referendum still be held? BBC, 31-012020. Available at: https://bbc.in/33Lfpv8.

Swenden, W. (2010). The Belgian Regions and the European Union: Unintended Partners in Unravelling the Belgian State? In R. Scully and R. Wyn Jones (eds.). Europe, regions and regionalism (pp. 16-34). London: Palgrave MacMillan. Available at: https://doi. org/10.1057/9780230293151_2.

Syal, R. (2014). Independent Scotland "would find it extremely difficult to join the EU". The Guardian, 16-02-2014. Available at: https://bit.ly/3mNlzUj.

The Economist. (2014). How did it come to this?, 10-07-2014. Available at https://www. economist.com/britain/2014/07/10/how-did-it-come-to-this.

Thorhallsson, B. (2000). The Role of Small States in the European Union. Farnharm: Ashgate 2000.

Ubieto, G. (2017). ¿Están los catalanes a favor del catexit? El Periódico, 28-11-2017. Available at: https://bit.ly/32MiSdr.

Vicens Vives, J. and Llorens, M. (1958). Industrials i Politics. Barcelona: Vicens Vices.

Walter, B. (2006). Information, uncertainty and the decision to secede. International Organization, 60, 105-135. Available at: https://doi.org/10.1017/S002081830606004.

Weatherill, S. (2005). The Challenge of the Regional Dimension in the European Union. In S. Weatherill and U. Bernitz (eds.). The Role of Regions and Sub-national entities in Europe (pp. 1-33). Oxford: Hart.

Weiler, J. H. H. (2012). Catalonian Independence and the European Union. EJIL: Talk! [blog], 20-12-2012. Available at: https://bit.ly/3iT9Sc7.

- (2019). A nation of nations? International Journal of Constitutional Law, 17 (4), 1301 1306. Available at: https://doi.org/10.1093/icon/moz097.

Wittman, D. (2000). The wealth and size of nations. The Journal of Conflict Resolution, 44 (6), 868-884. Available at: https://doi.org/10.1177/0022002700044006010.

Wivel, A. (2005). The Security Challenge of Small EU Member States: Interests, Identity and the Development of the EU as a Security Actor. Journal of Common Market Studies, 43 (2), 393-412. Available at: https://doi.org/10.1111/j.0021-9886.2005.00561.x. 
(2010). From Small State to Smart State: Devising a Strategy for Influence in the European Union. In R. Steinmetz and A. Wivel (eds.). Small States in Europe (pp. 15-29). Farnharm: Ashgate.

Zacher, M. (2001). The Territorial Integrity Norm: International Boundaries and the Use of Force. International Organization, 55 (2), 215- 250. Available at: https://doi.org/ $10.1162 / 00208180151140568$. 